\title{
Adoption of e-Government in the Republic of Kazakhstan
}

\author{
Yerlan Amanbek 1,2,*iD, Ilyas Balgayev ${ }^{2}$, Kanat Batyrkhanov ${ }^{2}$ and Margaret Tan ${ }^{2}$ \\ 1 Department of Mathematics, Nazarbayev University, Nur-Sultan 010000, Kazakhstan \\ 2 Nanyang Technological University, Singapore 637718, Singapore; ilyasbalgayev@yahoo.com (I.B.); \\ kanatbat@mail.ru (K.B.); mjytan@gmail.com (M.T.) \\ * Correspondence: yerlan.amanbek@nu.edu.kz
}

Received: 8 May 2020; Accepted: 6 July 2020; Published:9 July 2020

\begin{abstract}
Information and Communication Technology has been gaining importance in the economy of Kazakhstan, the largest landlocked country. In this paper, we investigate the factors that influence Kazakhstan's e-Government portal use at the informational stage and describe the challenges encountered by citizens while using the portal. Statistical analysis is performed on a web-based questionnaire survey targeted at citizens of Kazakhstan. The technology acceptance model is used as a methodology to measure attitude towards portal usage. This paper also discusses the barriers that can restrict the successful adoption of e-Government services. The results show that awareness among citizens is high and they perceive the portal to be useful, but only a limited percentage of citizens actually use it regularly. The results of this paper could be used to help the IT managers of the portal to improve the management of informational content and maintain more effective adoption among citizens.
\end{abstract}

Keywords: Technology Acceptance Model (TAM); e-Government; The Republic of Kazakhstan

\section{Introduction}

Governments and public organizations over the world have taken advantage of the Internet and Information and Communication Technologies (ICT). This can be observed from the fact that the governments of industrialized and developing countries have utilized and made investments into e-services and e-Government [1]. In [2], e-Government was explained as an information technology that enables and improves the efficiency with which government services are provided to citizens, employees, businesses, and agencies. With the help of e-Government, state organizations derive many benefits in terms of time and cost reduction, as well as the general growth of effectiveness of civil agencies while offering services to citizens. Many industrialized countries, such as the USA, Singapore, Australia, and the Netherlands, have succeeded in the development and implementation of the e-Government concept. Singapore has developed a consistent and integrated way to computerize the government sector. In 1980, it realized the significance of IT in establishing its economy [3] and, at present, Singapore's e-Government program stands among the most developed in the world. Clear vision and strong leadership have become the main factors that underlie the success of e-Government in Singapore. While industrialized countries have introduced the use of e-Governments, developing countries have also started to undertake e-Government initiatives by adapting existing previously created models within their own context. Many countries are trying to introduce e-Government concepts with high enthusiasm, but they do not always consider the prerequisites and concurrent management issues $[4,5]$.

According to [6], 35 percent of e-Government initiatives fully failed in implementation, 50 percent partially failed, and only 15 percent were successful. However, several developing countries, such as 
Brazil, India, and Chile, have prospered in their implementation of e-Government initiatives [7]. In addition, several publications have appeared documenting e-Government experience studies in Eastern European countries, which are transitioning from the command economy model to free market economies $[8,9]$. These examples show that governments of developing nations can effectively use and appropriately employ the advantages of ICT. It has been recognized that there is a significant gap between advanced and developing countries in e-Government development, but it is believed that developing countries can learn from industrialized countries [10].

As the Kazakhstan e-Government portal is considered to be a main gateway to all state departments, units, and their electronic services, we focus on and investigate the challenges in its usage in this paper. We only focus on the informative functionalities and features of the portal. In the digital age, the government tend to adapt the advances of ICT in order to design online platforms between government and public sectors. The e-Government portal can be seen as part of innovative system in Kazakhstan.

In this paper, we investigate the challenges and influencing factors encountered by citizens of Kazakhstan in using the e-Government portal at the informational stage through the Internet technology. This paper contributes to the available literature that discusses the adoption of e-Government in developing countries, including the post-soviet countries. The research question of this work is: what are the key factors that demonstrate citizens' perspective toward adopting e-Government portal?

The rest of the paper is organized, as follows: Section 2 is devoted to a background, including the e-Government of Kazakhstan and a literature review. In Section 3, the methodology, including data analysis, is presented. Section 4 describes the result of the analysis and Section 5 discusses e-Government in the Republic of Kazakhstan and Open Innovation. Section 6 summarizes the results of this work and draws our conclusions.

\section{Background}

\subsection{E-Government of the Republic of Kazakhstan}

The Republic of Kazakhstan is located in Central Asia, at the intersection of Europe and Asia, and it is the largest landlocked country in the world. Such a vital location between China and Europe provides opportunities, playing a connecting role between these financial regions. In addition, the objective of the government is to diversify the economy of Kazakhstan, which primarily depends on the oil and gas industry of the country. One of the country's goals is also to be among the fifty most competitive countries in the world by 2030. Therefore, the Republic of Kazakhstan, which is a developing country, is trying to build an informational society that is based on the use of ICT. This is important factor in the above-mentioned ranking.

According to the Nation Address of President of the Republic of Kazakhstan [11], the Agency of Information and Communication was initially developed as the National Program for Developing e-Government in the Republic of Kazakhstan between 2005-2007. This was one of the serious steps carried out to build a highly technologically developed government. The main objective of introducing the e-Government was to increase the quality and effectiveness of public administration and public services. The e-Government aims to automate the activities of state agencies, which could allow citizens to more effectively use highly demanded e-services. In 2009, Kazakhstan's government was struggling with challenges, such as a bureaucratic pattern in governance, complications caused by redundancies in public sectors, and shortages in co-ordination, and proper information dissemination among governmental sectors. Most of these problems were planned to be eliminated with the effective use of ICT, by establishing one centralized database where all relevant information regarding a particular citizen would be electronically accessible to authorized parties whenever it is needed. The creation of the e-Government in Kazakhstan is a long-term process, which was planned to be implemented through three sequential stages: the initial, informative stage (from 2005 to 2006) included 
a single access point to all information resources of the state bodies. During this stage, initiators conducted orientation towards citizens, provided information regarding the needs of organizations, proceeding from both life and business events. Within the framework of this stage, information about services of all state bodies was placed in the portal up to the end of 2006. Generally, it provided citizens with government-related information. The second, interactive stage involved implementing mechanisms of identification and authorization for users, citizens reception services, and a mobile version of the portal. After the completion of this stage, citizens would be able to send applications and inquiries in order to obtain specific information or complete a wide range of procedures through the Internet. The third, transactional stage fulfills the mechanism of citizens being able to access the payment of public services through the portal. This makes it possible to carry out financial transactions by means of the integration of a payment gateway and banking system. After the completion of this stage, citizens would be able to make payments related to public services through the Internet. The current fourth, transformation stage is still in progress. The main goal of the transformation stage is to maximize the efficiency in e-services provided to citizens. To achieve this, the interactive and transactional services are combined into integrated services, which are necessary for the citizens.

To make the realization of an e-Government feasible, only developing and introducing web-based applications is insufficient. The needs of facilitating a so-called "informational society" (i.e., people who possess sufficient computer literacy and inexpensive affordable access to ICT, who are able to interact with the government through the Internet regardless of their geographical location) must also be considered. In order to do this, the Agency of Information and Communication developed a program on "Reducing informational inequality program for years 2007-2009". This program, which totally costed around US\$1 million, aimed to increase the number of active Internet users by 20 percent in Kazakhstan's population by the end of 2009. The main objectives of the program were to reduce the cost of Internet connections, provide social computers at affordable prices, and form an interest in ICT among Kazakhstan citizens. The Agency distributed numerous booklets among the population, organized "round tables" about e-Government, and offered free training for citizens. Nevertheless, an awareness of this initiative among citizens was low. As was stated in [12], most of the money was spent on technical aspects of the project and the Agency's efforts were not enough. In 2009 , there were many reasons for the unpopularity of the e-Government portal. One of the issues was the level of trust of the population with respect to electronic governmental resources. In [13], it was also stated that a large amount of the budget was allocated to improving the IT infrastructure in the beginning of e-Government portal.

At present, the e-Government system is in its fourth stage of development, the so-called transformational stage. In other words, most services to citizens are to be combined, in order to achieve efficiency [14]. According to the UN e-Government Development Index [15-20], the progress of Kazakhstan's rank in 10 years is substantial; in fact, it has increased twice (see Table 1). In addition, the number of e-Government system users increased from 10,960 users in 2009 to 8.6 million in 2018 (an 800 times increase) [21]. However, in the last four years, we have observed a tendency of decline in the Kazakhstan rank. In [22], the necessity of examining of the adoption of e-Government in the Kazakh Society was highlighted. In 2018, the economy of Kazakhstan faced a challenging time, as they had in 2009, as the oil and gas industry (a main driver of the Kazakhstan economy) were continuing to recover slowly. However, the coronavirus pandemic situation in 2020 has worsened the financial condition globally. This unprecedented situation has pushed the IT system to help many people in communications, distance learning, remote working, and so on. Further improvement of e-Government in a systematic way can prepare the country for challenges, such as limited financial resources. The coronavirus pandemic situation has accelerated the use of e-Government services, e-learning, and online systems. On the other hand, it has revealed gaps in the ICT infrastructure, as well as the unpreparedness of systems and organizations for such a situation. Users are forced to learn and rely on more e-services. 
Table 1. e-Government Development Index for Kazakhstan.

\begin{tabular}{ccccccc}
\hline Kazakhstan & $\mathbf{2 0 1 8}$ & $\mathbf{2 0 1 6}$ & $\mathbf{2 0 1 4}$ & $\mathbf{2 0 1 2}$ & $\mathbf{2 0 1 0}$ & $\mathbf{2 0 0 8}$ \\
\hline e-Government Development Index Rank & 39 & 33 & 28 & 38 & 46 & 81 \\
\hline
\end{tabular}

\subsection{Literature Review}

To understand the factors that are encountered by citizens, we chose the Technology Acceptance Model (TAM), which is used as a model to measure attitude toward technology adoption in multiple domains. Subsequent studies have confirmed the usefulness of TAM and its various extensions and revisions as a tool for investigating and predicting user information technology acceptance [23-29]. In addition, for several years, great effort has been devoted to the study of usage of e-Government by TAM in many countries [30-33].

In [34], it was shown that the factors that determine the adoption of e-Government services, as identified in particular developed countries, could be transferable in the context of developing countries.

The original TAM, as developed by Davis, describes a person's acceptance of a technology by his (or her) voluntary intentions toward using the technology [35]. TAM predicts user acceptance that is based on the influence of two factors: perceived usefulness (PU) and perceived ease of use (PEOU). Figure 1 shows the original TAM, which states that a user's perception of usefulness and ease of use determines their attitude toward using (AT) the system, where further behavioral intention to use (BI) is determined by this attitude. According to the TAM, behavioral intention determines actual system use (AU). TAM proposes a direct relationship between perceived usefulness and behavioral intention to use.

TAM offers a relatively simple and cost-effective way to predict whether a system is actually used ([36]).

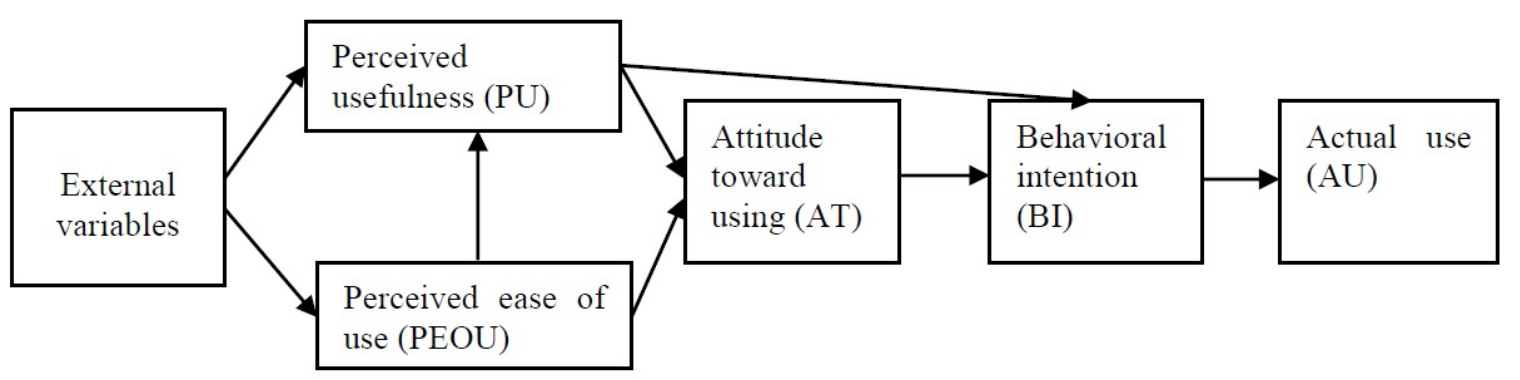

Figure 1. Original Technology Acceptance Model (TAM), adopted from [35].

Perceived usefulness is defined as the "subjective probability that using a specific application system will increase his or her job performance within an organizational context". Perceived ease of use stands for "the degree to which the user expects the target system to be free of efforts" [35]. Attitude toward using is described as a personal feeling about performing a target behavior [37]. Attitudes towards using is an object influencing intentions which, in turn, influences behavior with respect to the object [38]. Behavioral intention can be explained as the strength of one's intentions to use a technology in the future. In the context of technological acceptance, it is essential to measure attitude towards using and perceptions regarding the use of technology, rather than attitude and perceptions directed towards the technology itself, as people could have a positive view about a technology without positive feeling towards its use [39]. In [35], a revision of the original TAM was proposed, which the authors claimed to be a more powerful model for the prediction and explanation of user behavior. It was only based on such constructs as PU, PEOU, and BI; the AT construct was removed, due to the partial mediation of the impact of perception on intention by attitude. Later research on the TAM indicated that attitude may play a central mediating role in determining mandatory usage, but its direct relationship to behavioral intention was not supported [40,41]. Performance is key: intention 
forms with respect to performance considerations, rather than a person's feelings about performing a behavior [42]. The revised TAM, as shown in Figure 2, has a strong relationship between perceptions and intention. It has been shown that attitude may exist to correlate itself with usage behavior [39]. Freedom of choice has a significant impact on a person's acceptance of innovations [43]; for example, if some employees do not want to accept an innovation, they may even sabotage its implementation. In [44], this reaction was explained as a personal attitude, which drives employees in their form of hostility towards the technology.

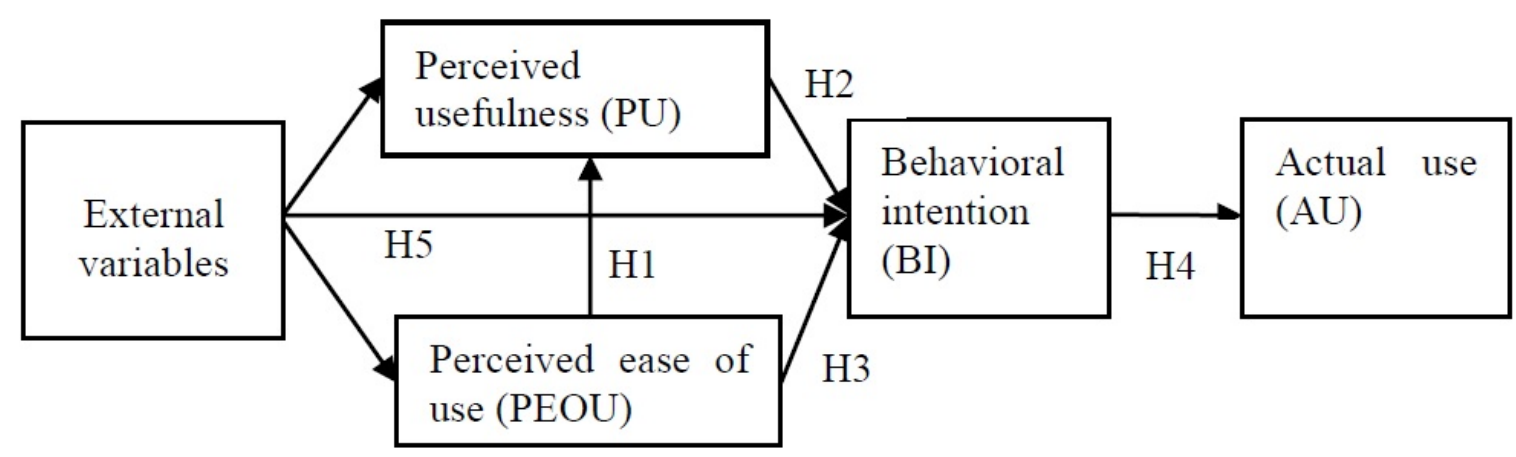

Figure 2. Revised TAM.

\subsection{Hypotheses}

According to [35], PEOU has a direct influence on perceived usefulness. In [26], it was mentioned that, between two systems with similar features and functionalities, the user should find the one that is easier to use and is more useful. In [35], it was stated that, if a user works more productively because of enhancement of ease of use, then he or she should work more productively overall.

Hypothesis 1 (H1). Perceived ease of use has a positive influence on perceived usefulness.

TAM states that both PU and PEOU constructs have a significant impact on user acceptance. Many studies have initially described PU to be more important than PEOU and that PEOU has no direct relationship to AU [45]. In [35], it was found that, in the early stages, PEOU has a stronger impact on intention; however, with time and experience, it was found that the effect is indirect, operating through PU. However, it would be fair to say that no amount of PEOU can compensate for low usefulness [46]. The role of PEOU in TAM has an equal or even stronger effect than the role of PU on technology adoption [47]. For example, people intend to use the technology if they perceive it to be useful, but, if the technology is not easy to use, this could lead to an avoidance of usage.

Hypothesis 2 (H2). Perceived usefulness has a positive influence on behavioral intentions to use.

Hypothesis 3 (H3). Perceived ease of use has a positive influence on behavioral intentions to use.

There is a direct and positive effect between behavioral intention to use the portal and actual use of the portal. Research on TAM has consistently demonstrated strong empirical support for this relationship: intentions can accurately explain and predict actual behavior.

Hypothesis 4 (H4). A behavioral intention to use has a positive influence on actual use.

Many studies have tested the effects of external variables on PEOU and PU [47,48]. Both [49] and [50] discussed the independence of PEOU and PU from the effects of external variables. However, Agarwal and Prasad [51] found that PEOU and PU totally mediated the impact of external 
variables on user attitudes and intentions to use it. The Theory of Reasoned Action (TRA) [37] states that external variables only influence attitude through user perceptions about the technology.

In our study, we used academic level and occupation as the external variables that have an influence on behavioral intention towards the use of the e-Government portal.

Hypothesis 5 (H5). External factors (academic level and occupation) have a significant impact on behavioral intentions to use.

\section{Methodology}

We conducted quantitative research through a web-based survey to discover the perception towards the portal. In [52], the advantages of web-based surveys were noted, such as structured responses, possibility to point-and-click responses, transfer over an electronic medium of data and its comparison, visual representation of the questions, flexible time constraints, and constructing questions in an advance manner to reduce the number and complexity of questions presented to users. We used the "SurveyMonkey.com" web site to create and publish the questionnaire. This web site offers the transformation of URLs into direct links to the web site, which can lead to the minimization of additional actions on behalf of the respondents, as suggested by [53].

\subsection{Questionnaire Design}

The questionnaire consisted of three sections and had 23 questions. The first section captured questions concerning the external factors that are associated with e-Government portal usage. The second section examined factors on perception of the e-Government portal through the TAM. These factors consisted of perceived ease of use, perceived usefulness, behavioral intention, and actual use. The third section set out to capture the general profile of respondents. Please see Appendix A for detailed information.

A seven-point Likert scale was used, ranging from " 1 "—-strongly agree to "7"—strongly disagree. The survey lasted for one week, from 12 to 19 March 2009. Because the questionnaire was originally constructed in English, it was necessary to translate it into Kazakh and Russian, the locally spoken languages. The questionnaire was designed to be short, unambiguous, and easy for the respondents to complete. Constructs and statements that were relevant to the study were adopted from a variety of sources, mainly past studies [26,27] and research papers with similar interests $[23,24,54-56]$, and modified to suit the current research context.

\subsection{Data Analysis}

The target respondents for the survey were Kazakhstan citizens. Invitations for participation in the survey were shared in social networking websites, blogs, among our ex-colleagues, friends, friends of friends, family members, and so on. The information about this study were spreading in many online platforms, e.g., the social networking websites, such as facebook, vkontakte, moi mir, etc.

The Statistical Package for the Social Sciences (SPSS) software was used to analyze the data and determine the existence of relationships. We used the statistical techniques known as correlation and regression. The correlation coefficient measures the strength and direction of the relationship. If the value of the correlation coefficient is closer to +1 or -1 , then the linear relationship is stronger or weaker between two variables [57], respectively. As the numbers of items for the PU, PEOU, and BI were more than one, as shown in Table 2 and Table A1 (in Appendix B), the principal components factor analysis was performed. Details are in Appendix C, Tables A5-A7. Principal components factor analysis is a method for re-expressing multivariate data. It allows for a reorientation of the data, such that the first few dimensions account for as much of the available information as possible. If there is substantial redundancy present in the data set, then it may be possible to account for most of the information in the original data set with a relatively small number of dimensions [58]. In addition, 
we used Kaiser's Varimax rotation to achieve a simple structure by focusing on the columns of the factor loadings matrix.

Table 2. Number of questions allocated for TAM constructs.

\begin{tabular}{ccc}
\hline Construct & Number of Items & Question Number \\
\hline PU & 23 & Q9, 11 and 12 \\
PEOU & 24 & Q10, 13 and 14 \\
BI & 6 & Q15-16 \\
AU & 1 & Q8 \\
\hline
\end{tabular}

As the properties of the key variables in the hypotheses were different, two approaches-Linear regression and Independent Sample T-test-were conducted to test for correlations. Details of the variables for the hypotheses are presented in Table A4 (Appendix C).

Hypothesized relationships were previously tested by using regression analysis to maintain consistency. For our research, a stepwise multiple regression analysis technique is recommended to examine the influence of each predictor variables to the regression model [59]. As one of the multiple regression types, linear regression was applied to facilitate the analysis. Particularly, linear regression analysis is a tool with several important applications. It is a way of testing hypotheses regarding the relationship between numerical variables and estimating the specific nature of such relationships [60]. Linear regression investigates the relationships between predictor variables (i.e., independent variables) and outcome variables (i.e., dependent variables). Another approach was the $T$-test, which identifies the significance of difference between two means. One of the most commonly used T-tests is the Independent Samples T-test. We can use this test when we need to compare the mean of two independent samples on a given variable. In [61], conducting the Independent Samples T-test is suggested when one variable is categorical and the other, dependent one is numeric.

\section{Findings}

\subsection{Overview of Respondents}

We sent out 300 emails and the response rate was 219 (73 percent), where 60 percent of respondents were male and 40 percent were female. Two age groups were represented by almost all respondents, where the majority of respondents were from the first age category, 16-25 (71\%), while the second category was people of age $26-35$ years old (16\%). This could be mostly explained by the method of the survey distribution, which was non-random. In terms of education, $53 \%$ of respondents held a bachelor degree, whereas a master's degree was held by $50 \%$ of respondents. The number of PhDs who participated in the survey was low $(2 \%)$. The demographic profile results are presented in the Table 3.

Table 3. Demographic profile.

\begin{tabular}{ccc}
\hline & Category & Percentage \\
\hline \multirow{2}{*}{ Gender } & Male & 59.6 \\
& Female & 40.4 \\
\hline \multirow{4}{*}{ Age } & $16-25$ & 71.3 \\
& $26-35$ & 16.4 \\
& $36-55$ & 7.6 \\
Academic level & 56 and above & 4.7 \\
\hline & High school & 15.2 \\
& University Bachelor & 52.6 \\
& University Master & 29.8 \\
& University PhD & 2.3 \\
\hline
\end{tabular}


In terms of occupation, people from finance (19\%) and IT (15\%) backgrounds were involved actively, but the percentage of students was the highest (32\%). In 2009, a salary range of 75,001-150,000 tenge (US\$501-1000) led the list (31\%); the second place was a salary range of 150,001-300,000 tenge (US\$1001-2000) with portion of 23\%. Almost two-thirds of respondents claimed Almaty (50\%) and Astana (22\%) as their cities of residence. The results showed that the majority of respondents $(51 \%)$ used the Internet more than ten hours per week and $22 \%$ used it from one to four hours, accordingly. A total of $52 \%$ of respondents accessed the Internet from home, while $38 \%$ did from work. However, we had cases where both access points were stated $(6 \%)$. Broadband connection type was the common answer $(65 \%)$, while a dial-up connection was the second most common answer (30\%). The usual price for the Internet connection was in the range of $0-4500$ tenge (US\$0-30), for $74 \%$ of respondents.

\subsection{Respondent Awareness of e-Government Portal}

It was found that $81 \%$ of participants were aware of the e-Government portal. In this set of people, $69 \%$ had visited the portal at least once. Of those who answered the question "How many times do you visit the e-Government portal per week?", only $20 \%$ indicated that they used the portal on a regular basis; that is, one or more times per week (see Tables 4 and 5). The top three informational sources that promoted the portal were web sites, TV, and information from friends and family members. Figure 3 presents the sources of how people knew about the portal.

Table 4. Awareness of the portal.

\begin{tabular}{ccc}
\hline Question & Yes & No \\
\hline Have you ever heard about e-government portal ? & $80.82 \%$ & $19.18 \%$ \\
\hline Have you ever visited the Kazakhstan's e-Government portal? & $68.97 \%$ & $31.03 \%$ \\
\hline
\end{tabular}

Table 5. Actual use.

\begin{tabular}{ccc}
\hline Question & More than 1 Times & Less than 1 Times \\
\hline How many times do you visit the e-Government portal per week? & $20 \%$ & $80 \%$ \\
\hline
\end{tabular}

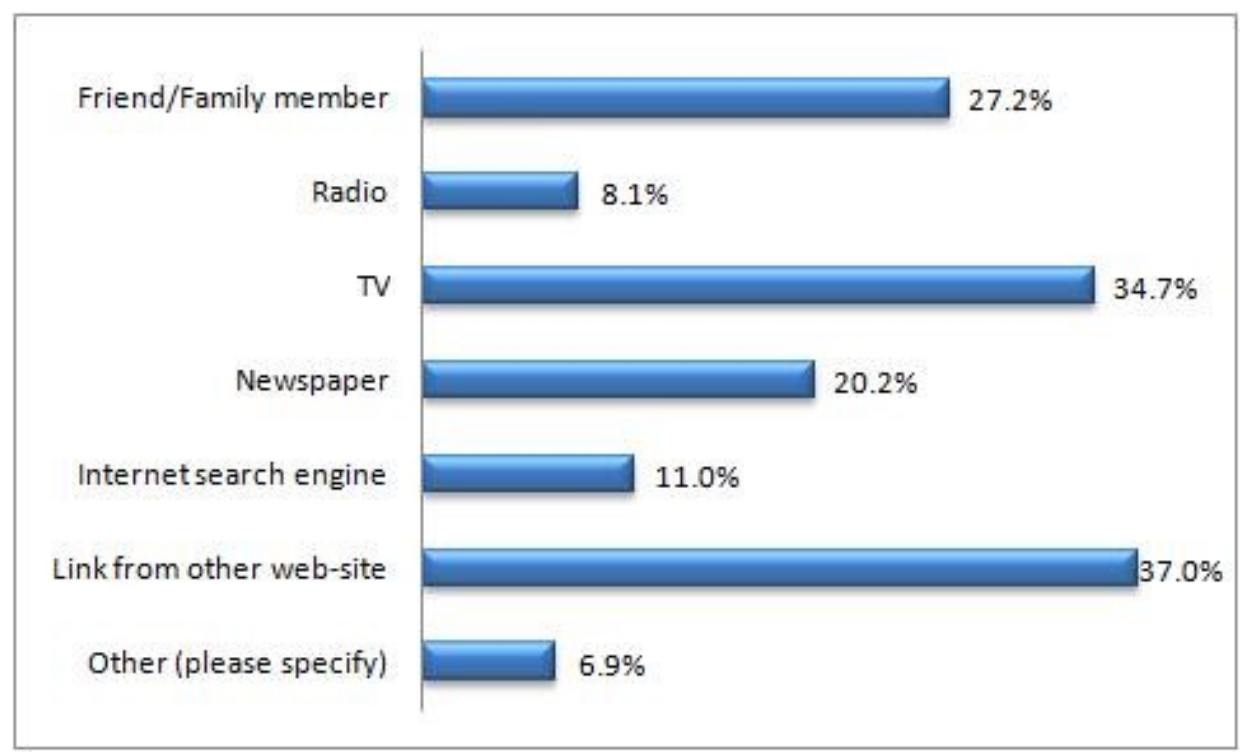

Figure 3. Summary of the answers for question: "How did you know about Kazakhstan e-Government portal?".

As our respondents were young people who used Internet frequently, web sites were the most popular source (37\%). In addition, the government pays attention to mass media channels, such as 
$\mathrm{TV}$, radio, and newspapers, which were ranked highly (e.g., 35\% for TV). The viral marketing effect took place in promotion of the e-Government portal when a person disseminated information among friends, friend's friends, and family members $(27 \%)$.

\subsection{Actual Users}

The actual user group was the respondents who used the e-Government portal regularly (more than one time per week), comprising 20\% of all respondents. They are indicated in Table 6 . There was no significant difference between genders, with $53 \%$ males and $47 \%$ females. Both males and females were almost equally involved in portal use. Most frequent people who used the portal were in range of 16-25 years old (47\%), followed by age group of 26-35 (29\%). The number of respondents that used the portal reduced with increasing age. In the context of Kazakhstan, older people do not use the Internet or even computers as frequently as the youth do. Citizens with a master degree comprised $42 \%$ and those who had a bachelor degree comprised $35 \%$ of the respondents. None of the PhDs used the e-Government portal on a regular basis. Therefore, the majority of actual users had academic degrees. It can be explained that the associated content was interesting and useful for educated people, but not very dedicated for others. People with bachelor and master degrees more widely use the Internet and, so, there is a higher level of awareness of e-Government among these groups of people. Historically, Kazakhstan's education system was inherited from the Soviet system, where scholars at the age of around 40-50 usually earn a PhD or Doctor of Science degree. Assuming that the majority of Kazakhstan PhD degree holders are older than the age of 50, they may not use the Internet expertly and prefer traditional methods of searching for information and interacting with the government; the reader is referred to Table 6 .

Table 6. Demographic profile of actual users.

\begin{tabular}{clc}
\hline & Category & Percentage \\
\hline \multirow{2}{*}{ Gender } & Male & 53 \\
& Female & 47 \\
\hline \multirow{4}{*}{ Age } & $16-25$ & 47 \\
& $26-35$ & 29 \\
& $36-55$ & 23 \\
\hline \multirow{4}{*}{ Academic level } & High school & 23 \\
& University Bachelor & 35 \\
& University Master & 41 \\
\hline
\end{tabular}

The majority of respondents who used the portal on a regular basis had a broadband connection (65\%). Prices for internet access have become relatively low, when compared to that in the year 2007, when an unlimited dial-up plan was US\$111 and a 1.5 Mbps connection was US\$3355 (Anderson, 2007) [62]. It is clear that the availability of the Internet became more affordable. Today, the Kazakh "state-owned" telecom provider offers a broadband connection at the monthly price of 1930 tenge (US\$ 12.8).

The top three categories of occupation were government workers (35\%), students ( $29 \%)$, and IT specialists $(18 \%)$. None of the surveyed unemployed and sales people used the e-Governmental portal. Government workers likely used the portal, because it was directly related to their work. While using the portal, IT workers might find it useful and generally could be interested in e-Government initiatives. Students were the major group of respondents of the survey, who may have been interested in the education sector.

It was found that citizens from Astana used the e-Government portal more often than citizens from Almaty and other regions did. Astana is the capital city of the Republic of Kazakhstan and many of Astana's citizens work in the government sector. Naturally, the citizens of Astana are much closer to the government and more involved in governmental programs and initiatives. 
Actual users were people mostly with an income level of 75,001-150,000 tenge (US\$501-1000) for a total of $47 \%$, followed by the second group with income level of 15,001-75,000 tenge (US\$100-500), comprising $35 \%$. Together, these two groups contained $82 \%$ of actual users and they dominated over other groups. These groups determine the middle class of Kazakhstan citizens.

\subsection{Barriers for Not Using the e-Government Portal}

Of those respondents who had not used the portal (31\%), we asked them for reasons why they had not used the portal. Please refer to Figure 4.

The majority of respondents $(72 \%)$ stated that they did not think that they needed to use the e-Government portal. The initiative might be new for the population and citizens have not become accustomed to this concept. It could be explained from the point that it is much easier for people to get information through phone calls, mail requests, or face-to-face communication. Therefore, the government should encourage people to use it through well-managed and well-promoted plans for breaking this line of resistance.

Another important aspect was absence of useful information (about 17\%). This means that the provided information was too generic and might not satisfy user needs. The portal provides external web links for details about particular matters, which could have been insufficient, as participants said that they were not useful enough.

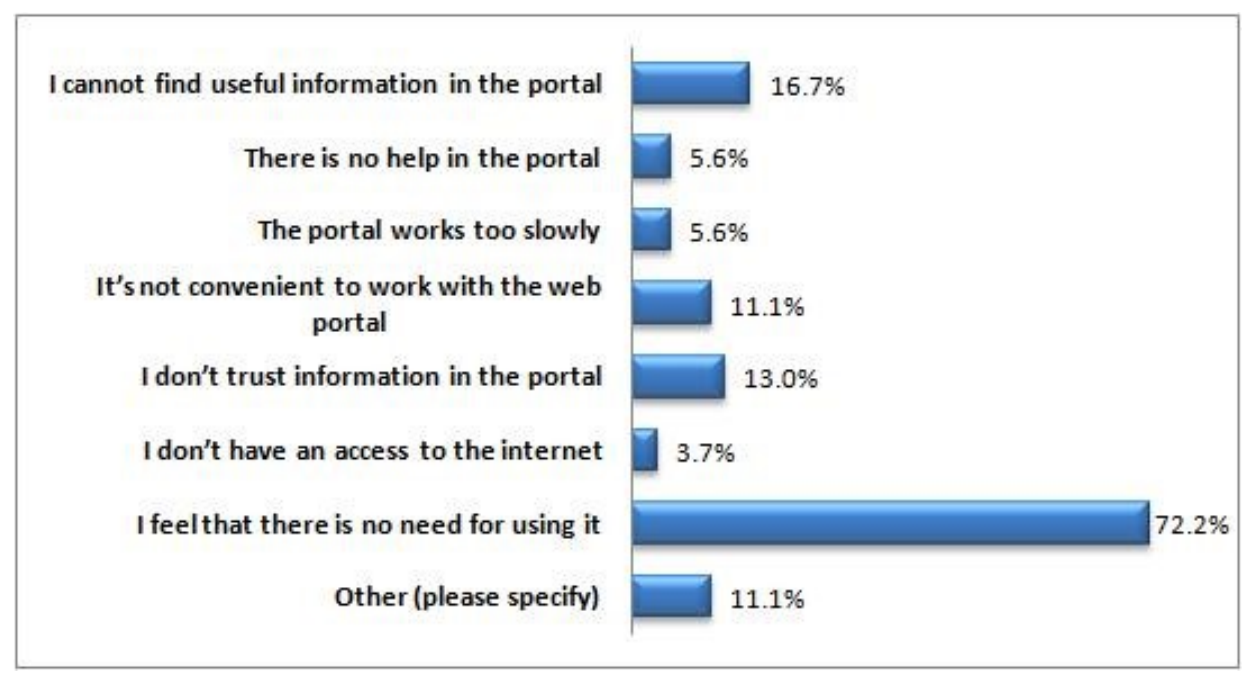

Figure 4. Barriers for not using e-Government portal.

It was interesting to note that $13 \%$ did not trust the information in the portal. This can be partially explained by the fact that citizens are required to provide personal information (ID) in order to register as a legal user. A number of websites of different governmental departments have been attacked by hackers; therefore, people might feel that their identity could be stolen and used in criminal actions.

\subsection{Content of e-Government Portal}

We also investigated the most useful information sectors and information about services, their relevance, and potential. Tables 7 and 8 present a list of the top three informational sectors and information about services, respectively. Full ranking tables are available in the Appendix E, in Tables A10-A13.

In terms of sectors, education, health, and employment were seen to be the three top most useful information sectors. The majority of respondents were students, who felt that education and employment information sectors were important for them. However, health was the common aspect for any group of people. 
Table 7. Ranking of information sectors.

\begin{tabular}{ccc}
\hline \multirow{2}{*}{ Sectors } & \multicolumn{2}{c}{ PU } \\
\cline { 2 - 3 } & Mean & Std. Deviation \\
\hline Education & 2.6 & 1.321 \\
Employment & 2.68 & 1.371 \\
Health & 2.73 & 1.394 \\
\hline
\end{tabular}

The top three results that were based on usefulness of the transportation service information were airports, municipal reference services, and railroad stations. Such transportation services were interesting for citizens due to dynamic movement in the large territory of Kazakhstan.

Table 8. Ranking of information about services.

\begin{tabular}{ccc}
\hline \multirow{2}{*}{ Services } & \multicolumn{2}{c}{ PU } \\
\cline { 2 - 3 } & Mean & Std. Deviation \\
\hline Airports & 2.98 & 1.537 \\
Municipal reference services & 2.98 & 1.705 \\
Railroad stations & 3.03 & 1.553 \\
\hline
\end{tabular}

In addition, the participants felt that portal was not convenient to browse. Many of the functionalities were still under implementation, and the content and structure of the portal could change over a short period. This may confuse people and detract from further usage. In fact, most of the respondents had a positive perception regarding the usefulness of the e-Government portal (PU mean value was 3.07 out of 7); however, the majority felt that the information did not fully satisfy their needs. Generally, the respondents claimed that the portal was easy to use and they did not feel that they needed help while using it (PEOU mean value was 3.47 out of 7).

It is important to note that the overall intention of participants concerning e-Government portal usage was positive (BI mean value was 3.19 out of 7). In particular, the participants indicated that they would use the portal to reduce time spent and get latest information and news. We face a contradiction in the situation where the majority intends to use e-Government portal, but, in reality, they do not use it.

\subsection{Summary of Research Result}

Hypothesis 1 examined the link between perceived usefulness and perceived ease of use of the e-Government portal. The value of usability was directly related to the value of usefulness of the portal. This hypothesis was accepted $(p<0.01)$.

Even though the web portal provides useful information, if users are not able to obtain it due to poor ease of use, it might fail to satisfy their needs and users may not visit portal again. This empirical finding indicates that ease of use is the significant determinant for the portal usefulness.

Hypothesis 2 examined the link between perceived usefulness and behavioral intention; generally, participants intended to use e-Government portal in the case that it satisfies their needs. The results of our analysis demonstrated that participants had a positive perception on the usefulness and their intention to use the portal was also positives. This hypothesis was accepted $(p<0.01)$.

Hypothesis 3 examined whether there is a positive influence on behavioral intention if a user perceives the portal as easy to use. The hypothesis was rejected $(p=0.08$, greater than the acceptable level of 0.05). Although the overall intention was optimistic (mean value was 3.19 out of 7), perceived ease of use towards behavioral intention was not significantly correlated. Although the e-Governmental portal is easy to use, from the user's point of view, it does not provide enough useful information. It appeared that troubles in finding needed information can lead to resistance in the intention to use. 
Hypothesis 4 examined the link between people's behavioral intention and actual use. The hypothesis was rejected $(p<0.139)$. People have a positive intention to use the e-Government portal, but their actual use remains low.

Hypothesis 5 examined whether there is an existence of significant correlation between behavior intention and external factors (occupation and academic level). The BI variable was dependent on PU, PEOU, occupation, and academic level variables. As a result, the Academic level variable and PEOU variable were excluded. The hypothesis was rejected. However, significant (5\%) correlations between behavior intention and both occupation and PU were found ( $p<0.01$ for PU and $p<0.05$ for Occupation). Tables A8 and A9 in Appendix D provide detailed results of hypotheses calculations. The hypotheses tests are summarized in Table 9. Figure 5 illustrates these results.

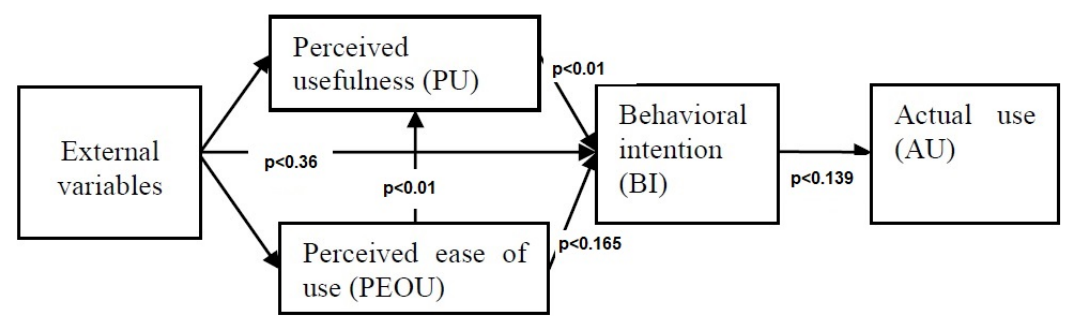

Figure 5. Results of hypotheses tests.

Table 9. Summary of hypotheses testing.

\begin{tabular}{clc}
\hline & Hypotheses & Result \\
\hline H1 & $\begin{array}{l}\text { Perceived ease of use has a positive influence on perceived usefulness of } \\
\text { e-Government portal }\end{array}$ & Accepted \\
\hline H2 & $\begin{array}{l}\text { Perceived usefulness has a positive influence on behavioral intentions to use } \\
\text { e-Government portal }\end{array}$ & Accepted \\
\hline H3 & $\begin{array}{l}\text { Perceived ease of use has a positive influence on behavioral intentions to use } \\
\text { e-Government portal }\end{array}$ & Rejected \\
\hline H4 & $\begin{array}{l}\text { A behavioral intention to use has a positive influence on actual use of } \\
\text { e-Government portal }\end{array}$ & Rejected \\
\hline H5 & $\begin{array}{l}\text { External factors (Academic level and Occupation) have a significant impact on } \\
\text { behavioral intentions to use e-Government portal }\end{array}$ & Rejected \\
\hline
\end{tabular}

\section{Discussion: The E-government in the Republic of Kazakhstan, and Open Innovation}

In the digital age, the government tend to adopt the advances of ICT to establish the online platform between the government and public sectors. The e-Government portal can be seen as part of an innovative system in Kazakhstan, which is a young country. The results of this study show important adoption factors between the innovative system of the government and users. The dynamic interaction between public and government via online systems plays an important role in the innovation system at the national level. Users from Kazakhstan indicate their feedback for new ICT tools and they are also a source of creative innovation.

On the other hand, the adoption of e-Government system cannot be implemented entirely by the Kazakhstan government's effort. It can be built by efforts of the public sector, private sector, and the participation feedback. The digital development of economy, business, public, and private sector is necessary to increase the adoption speed among users. According to the state program "Digital Kazakhstan" for 2018-2022, one of the main direction is to create an innovative ecosystem where innovative ideas transfer to the industry. Novel technology in the private sector stimulates to build trust among citizens toward modern technology. For example, main banks have started to implement the digital banking model that promotes online interaction between bank and clients by providing 
the user benefits [63]. In other words, the usefulness of the system attracts customers and motivates learning modern technology.

In the rapidly changing technological world, the advanced countries tend to use more innovation and it supports their competitiveness on the global market. For Kazakhstan, the transformation of technology innovation occurs horizontally by cooperation with foreign companies. Major local innovations cannot address some problems that require more financial support, technological advances, professionals, and appropriate infrastructure. That is why it is hard to observe a local and a revolutionary ICT development within a short time. However, the exchanging knowledge of local discoveries with global companies attracts more collaborations to achieve the economic sustainability.

Besides, the relationship between social, close, and market open innovation can be connected on the online websites. The connection between society and ICT through e-government stimulates the social innovations. This is beneficial for entrepreneurial enterprises. The complexity of open innovation system also requires the involvement of the different organizations from micro to macro systems. This study provides factors affecting the usage of e-Government system that can be key in integrating many organizations, including business, government, public sectors, and universities.

One of the element of the e-Government is open data. The main aim of the open data project is to provide transparency of the government institutions. In [64], it was stated that the nature of applications were data-driven applications based on the public dataset for desktop and mobile environments. This generates more startups with open data by engaging participants from universities, public sector, etc. According to [64], there are successful open data projects as mobile applications, for example, the Kindergardens of Astana, Post Offices, Cultural Astana, and Statistics of Regions. A reliable source of information is necessary for citizens on the internet.

In the pandemic situation, e-services are the only way to have interaction between the services of the government and citizens to control the spread of the virus. The pandemic situation accelerates the improvement of e-services and reveals gaps in the system at the current stage. The companies have accepted the use of online systems to be functional partially or fully.

\section{Conclusions}

The main purpose of the paper was to investigate the factors that influence the adoption of the Kazakhstan e-Government portal at the informational stage using the technology acceptance model. The research confirms that perceived usefulness is an important factor in the adoption of a e-Government portal. In order to increase its adoption rate, the developers of the e-Government portal should consider ways to improve the usefulness of the portal. The correlation between the usefulness and the easy to use was verified. This implies that the both factors are significant in the adoption of e-Government.

The findings of this research indicate that people know about the e-Government portal, perceive it to be useful and easy to use, and intend to use it; however, actual use is low. Barriers affecting the adoption of this portal were identified. The most significant one was that people do not think that they need to use it. We suggest that the government should start promoting the importance of the portal through mass-media channels, especially TV, newspapers, and publicizing information about it in reliable web-based information sources. The most useful information sectors and information about these sectors were identified.

People expect that the portal will solve the problem of bureaucracy and minimize the time taken to process inquiries, which particularly belong to the interactive and transaction stages of the development of the portal. However, the information provided in the portal typically does not match the needs of users. In particular, the respondents indicated that they could not find information within the portal and did not trust information in the portal, which, in turn, affects their intention to use. Trust is another important factor for the effective adoption of e-Government services. Therefore, it should be considered in all stages in the further implementation of the portal. Therefore, the matter of trust 
should be established from the beginning; for example, by possessing up-to-date news and information from complete and trustable sources.

Further research is desirable in order to obtain more explanatory features of the model for Kazakhstan using the representative population. In the pandemic situation with the quarantine regime, further study of the e-Government system would be of interest.

Author Contributions: Conceptualization, M.T.; methodology, I.B., K.B. and Y.A.; validation, Y.A. and K.B.; investigation, Y.A., I.B. and K.B.; writing—original draft preparation, Y.A., I.B. and K.B.; writing-review and editing, Y.A.; supervision, M.T.; funding acquisition, Y.A. All authors have read and agreed to the published version of the manuscript.

Funding: This work was partially supported by the Nazarbayev University, Grant No. 110119FD4502, the SPG fund and the Ministry of Education and Science of the Republic of Kazakhstan, Grant No. AP08052762.

Acknowledgments: First author would like to acknowledge the support from the FDCRG, No 110119FD4502, the SPG (Nazarbayev University) and the Minister of Education and Science of the Republic of Kazakhstan, No AP08052762.

Conflicts of Interest: The authors declare no conflict of interest.

\section{Appendix A}

\section{Questionnaire in English}

We are a group of young researchers from Nanyang Technological University (Singapore) doing research on user's perception towards the adoption of Kazakhstan's e-Government portal (www.e.gov.kz). The information we collect will be used purely for academic purposes. All individual responses will be kept in strict confidence. Your participation is voluntary and you can withdraw at any time. This is an anonymous survey, which means that your name and contact particulars are collected only for the purpose of obtaining your consent to participate and will not be attached to your survey response.

We appreciate your time and effort in helping us to complete this survey. Please answer the questions openly and we seek your honest opinion.

Thank you,

Yerlan Amanbek, Ilyas Balgayev, Kanat Batyrkhanov

w070057, yer10001, baty0001 @ntu.edu.sg

1. How frequently do you use the internet per week? (Please choose one option)

Less than $1 \mathrm{~h}$

1-4 h

5-9 h

More than $10 \mathrm{~h}$

2. Where do you usually access the internet? (Please choose one option)

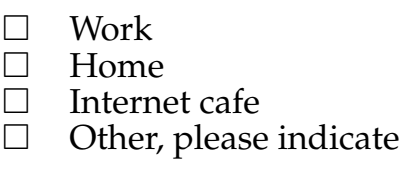

3. What is your internet connection type? (Please choose one option)
Dial-up
Broadband
Satellite

4. How much do you pay for internet connection per month? (Please choose one option) 
$\square \quad 4501$ tenge (US\$30)-7500 tenge (US\$50)

$\square 7501$ tenge (US\$51) and above

5. Have you ever heard about the Kazakhstan e-Government portal?

$\square \quad$ Yes

$\square \quad$ No (Please go to the question 18)

6. How did you know about Kazakhstan e-Government portal? (Please select as many as necessary)

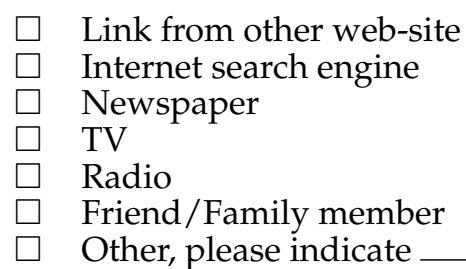

7. Have you ever visited the Kazakhstan's e-Government portal?

$\square \quad$ Yes

$\square \quad$ No (Please go to the question 18)

8. How many times do you visit the e-Government portal per week? (Please choose one option)

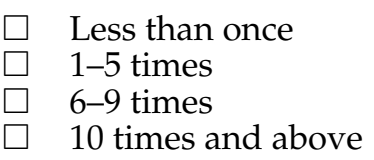

The following questions require You to answer them in likert-scale format. All the items employed a seven-point scale for measurement, with anchors of " 1 " indicating "Strongly agree" and " 7 " indicating "Strongly disagree".

9. With reference to the Kazakhstan e-Government portal I find the content:

\begin{tabular}{|c|c|c|c|c|c|c|c|}
\hline & $\begin{array}{l}\text { Strongly } \\
\text { agree }\end{array}$ & $\begin{array}{l}\text { Moderately } \\
\text { agree }\end{array}$ & $\begin{array}{l}\text { Slightly } \\
\text { agree }\end{array}$ & Neutral & $\begin{array}{l}\text { Slightly } \\
\text { disagree }\end{array}$ & $\begin{array}{l}\text { Moderately } \\
\text { disagree }\end{array}$ & $\begin{array}{l}\text { Strongly } \\
\text { disagree }\end{array}$ \\
\hline \multicolumn{8}{|l|}{ Current } \\
\hline \multicolumn{8}{|l|}{ Complete } \\
\hline \multicolumn{8}{|l|}{ Accurate } \\
\hline \multicolumn{8}{|l|}{$\begin{array}{l}\text { Non } \\
\text { redundant }\end{array}$} \\
\hline Useful & & & & & & & \\
\hline
\end{tabular}

10. With reference to the Kazakhstan e-Government portal I find ...

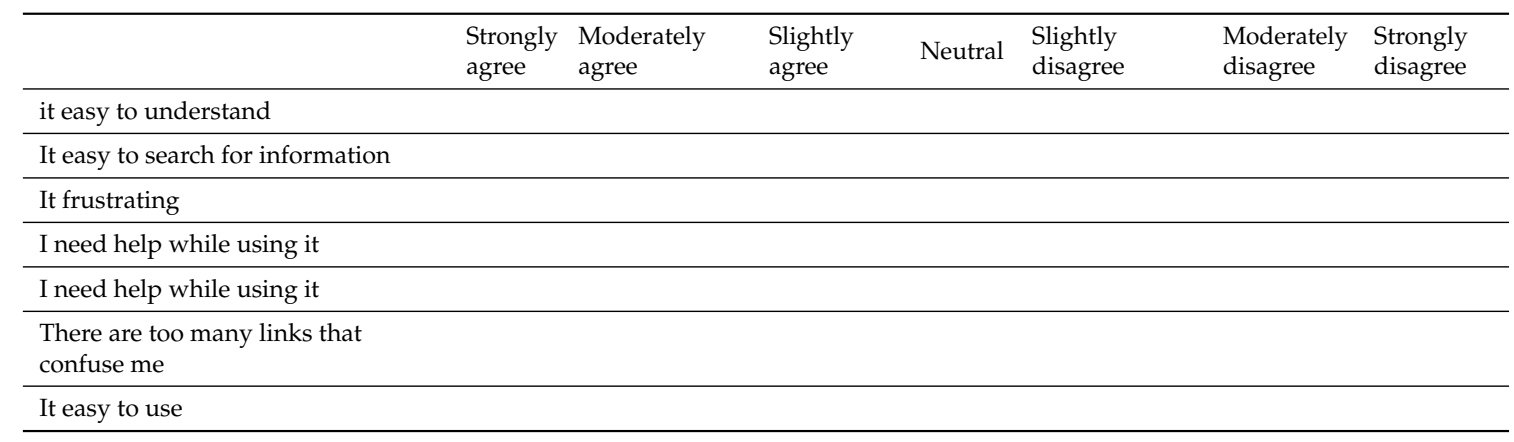

11. I find the information in following sectors useful: 


\begin{tabular}{|c|c|c|c|c|c|c|c|}
\hline & $\begin{array}{l}\text { Strongly } \\
\text { agree }\end{array}$ & $\begin{array}{l}\text { Moderately } \\
\text { agree }\end{array}$ & $\begin{array}{l}\text { Slightly } \\
\text { agree }\end{array}$ & Neutral & $\begin{array}{l}\text { Slightly } \\
\text { disagree }\end{array}$ & $\begin{array}{l}\text { Moderately } \\
\text { disagree }\end{array}$ & $\begin{array}{l}\text { Strongly } \\
\text { disagree }\end{array}$ \\
\hline \multicolumn{8}{|l|}{ Education } \\
\hline \multicolumn{8}{|l|}{ Health } \\
\hline \multicolumn{8}{|l|}{ Employment } \\
\hline \multicolumn{8}{|l|}{ Culture } \\
\hline \multicolumn{8}{|l|}{ Sport } \\
\hline \multicolumn{8}{|l|}{ Tourism } \\
\hline It easy to use & & & & & & & \\
\hline
\end{tabular}

12. I find the Information on following government and private services useful:

\begin{tabular}{|c|c|c|c|c|c|c|c|}
\hline & $\begin{array}{l}\text { Strongly } \\
\text { agree }\end{array}$ & $\begin{array}{l}\text { Moderately } \\
\text { agree }\end{array}$ & $\begin{array}{l}\text { Slightly } \\
\text { agree }\end{array}$ & Neutral & $\begin{array}{l}\text { Slightly } \\
\text { disagree }\end{array}$ & $\begin{array}{l}\text { Moderately } \\
\text { disagree }\end{array}$ & $\begin{array}{l}\text { Strongly } \\
\text { disagree }\end{array}$ \\
\hline \multicolumn{8}{|l|}{ Airlines } \\
\hline \multicolumn{8}{|l|}{ Motor transport } \\
\hline \multicolumn{8}{|l|}{ Airports } \\
\hline \multicolumn{8}{|l|}{ Railroad stations } \\
\hline \multicolumn{8}{|l|}{ Hotels } \\
\hline \multicolumn{8}{|l|}{ Transportation } \\
\hline \multicolumn{8}{|l|}{ Post } \\
\hline \multicolumn{8}{|l|}{ Internet } \\
\hline \multicolumn{8}{|l|}{ Telecommunications } \\
\hline \multicolumn{8}{|l|}{ Employment } \\
\hline \multicolumn{8}{|l|}{ Municipal reference services } \\
\hline Legal services & & & & & & & \\
\hline
\end{tabular}

13. I can find relevant and appopriate information that I need easily in the following sectors:

\begin{tabular}{|c|c|c|c|c|c|c|c|}
\hline & $\begin{array}{l}\text { Strongly } \\
\text { agree }\end{array}$ & $\begin{array}{l}\text { Moderately } \\
\text { agree }\end{array}$ & $\begin{array}{l}\text { Slightly } \\
\text { agree }\end{array}$ & Neutral & $\begin{array}{l}\text { Slightly } \\
\text { disagree }\end{array}$ & $\begin{array}{l}\text { Moderately } \\
\text { disagree }\end{array}$ & $\begin{array}{l}\text { Strongly } \\
\text { disagree }\end{array}$ \\
\hline \multicolumn{8}{|l|}{ Education } \\
\hline \multicolumn{8}{|l|}{ Health } \\
\hline \multicolumn{8}{|l|}{ Employment } \\
\hline \multicolumn{8}{|l|}{ Culture } \\
\hline \multicolumn{8}{|l|}{ Sport } \\
\hline \multicolumn{8}{|l|}{ Tourism } \\
\hline It easy to use & & & & & & & \\
\hline
\end{tabular}

14. I find using following information on government and private services easy to use: 


\begin{tabular}{|c|c|c|c|c|c|c|c|}
\hline & $\begin{array}{l}\text { Strongly } \\
\text { agree }\end{array}$ & $\begin{array}{l}\text { Moderately } \\
\text { agree }\end{array}$ & $\begin{array}{l}\text { Slightly } \\
\text { agree }\end{array}$ & Neutral & $\begin{array}{l}\text { Slightly } \\
\text { disagree }\end{array}$ & $\begin{array}{l}\text { Moderately } \\
\text { disagree }\end{array}$ & $\begin{array}{l}\text { Strongly } \\
\text { disagree }\end{array}$ \\
\hline \multicolumn{8}{|l|}{ Airlines } \\
\hline \multicolumn{8}{|l|}{ Motor transport } \\
\hline \multicolumn{8}{|l|}{ Airports } \\
\hline \multicolumn{8}{|l|}{ Railroad stations } \\
\hline \multicolumn{8}{|l|}{ Hotels } \\
\hline \multicolumn{8}{|l|}{ Transportation } \\
\hline \multicolumn{8}{|l|}{ Post } \\
\hline \multicolumn{8}{|l|}{ Internet } \\
\hline \multicolumn{8}{|l|}{ Telecommunications } \\
\hline \multicolumn{8}{|l|}{ Employment } \\
\hline \multicolumn{8}{|l|}{ Municipal reference services } \\
\hline Legal services & & & & & & & \\
\hline
\end{tabular}

15. I would like to use e-Government web portal because it helps me:

\begin{tabular}{|c|c|c|c|c|c|c|c|}
\hline & $\begin{array}{l}\text { Strongly } \\
\text { agree }\end{array}$ & $\begin{array}{l}\text { Moderately } \\
\text { agree }\end{array}$ & $\begin{array}{l}\text { Slightly } \\
\text { agree }\end{array}$ & Neutral & $\begin{array}{l}\text { Slightly } \\
\text { disagree }\end{array}$ & $\begin{array}{l}\text { Moderately } \\
\text { disagree }\end{array}$ & $\begin{array}{l}\text { Strongly } \\
\text { disagree }\end{array}$ \\
\hline \multicolumn{8}{|l|}{ To reduce my expenses } \\
\hline \multicolumn{8}{|l|}{ To reduce my time spent } \\
\hline \multicolumn{8}{|l|}{ To minimize bureaucracy } \\
\hline \multicolumn{8}{|l|}{ To get latest information and news } \\
\hline To get quick responses for inquiries & & & & & & & \\
\hline
\end{tabular}

16. Select your option

\begin{tabular}{|c|c|c|c|c|c|c|c|}
\hline & $\begin{array}{l}\text { Strongly } \\
\text { agree }\end{array}$ & $\begin{array}{l}\text { Moderately } \\
\text { agree }\end{array}$ & $\begin{array}{l}\text { Slightly } \\
\text { agree }\end{array}$ & Neutral & $\begin{array}{l}\text { Slightly } \\
\text { disagree }\end{array}$ & $\begin{array}{l}\text { Moderately } \\
\text { disagree }\end{array}$ & $\begin{array}{l}\text { Strongly } \\
\text { disagree }\end{array}$ \\
\hline $\begin{array}{l}\text { I would not use the portal as I am } \\
\text { currently using other sources for the } \\
\text { information I need (e.g.; informal } \\
\text { web sites, official resources and } \\
\text { mass media channels) }\end{array}$ & & & & & & & \\
\hline
\end{tabular}

17. What are the reasons for not using/visiting Kazakhstan e-Government web portal? (Please select as many as necessary)

$\square \quad$ I cannot find useful information in the portal

$\square \quad$ There is no help in the portal

$\square \quad$ The portal works too slowly

$\square \quad$ It's not convenient to work with the web portal

$\square \quad$ I don't trust information in the portal

$\square \quad$ I don't have an access to the internet

$\square \quad$ I feel that there is no need for using it

$\square$ Other, please indicate

\section{Demographic profile.}

18. Gender
$\square \quad$ Male
$\square \quad$ Female

19. Age

$\square \quad 16-25$
$\square \quad 26-35$ 
$\square \quad 36-55$

$\square \quad 56$ and above

20. Academic level
$\square \quad$ High school
$\square \quad$ University Bachelor
$\square \quad$ University Master
$\square \quad$ University PhD

21. Place of staying
$\square \quad$ Almaty
$\square \quad$ Astana
$\square$ Other, please indicate

22. Occupation

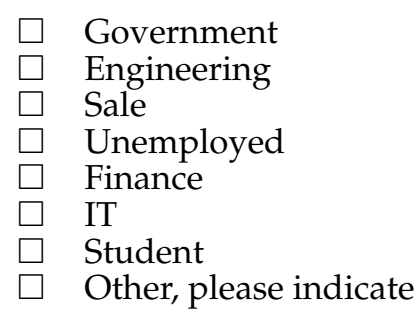

23. Salary range

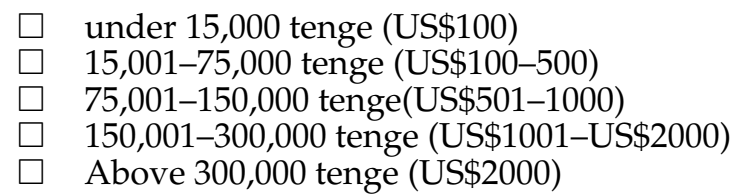

\section{Appendix B}

Table A1. Data coding (part 1).

\begin{tabular}{|c|c|c|c|}
\hline No. & Variable & Description of Variable & Valid Value \\
\hline Q1 & MFRQINT & $\begin{array}{l}\text { How frequently do you use the internet per } \\
\text { week? }\end{array}$ & $\begin{array}{l}\text { 1: Less than } 1 \mathrm{~h}, 2: 1-4 \mathrm{~h}, 3: 5-9 \mathrm{~h}, 4 \text { : More } \\
\text { than } 10 \mathrm{~h}\end{array}$ \\
\hline Q2 & MACCINT & Where do you usually access the internet? & 1:Work, 2: Home, 3: Internet cafe, 0: other \\
\hline Q3 & MCONTYP & What is your internet connection type? & 1: Dial-up, 2: Broadband, 3: Satellite \\
\hline Q4 & MINTCOST & $\begin{array}{l}\text { How much do you pay for internet } \\
\text { connection? }\end{array}$ & $\begin{array}{l}\text { 1: } 0-4500 \text { tenge (US\$30), } 2: 4501 \text { tenge } \\
\text { (US\$30)-7500 tenge (US\$50), 3: } 7501 \text { tenge } \\
\text { (US\$51) and above }\end{array}$ \\
\hline Q5 & MHEARD & $\begin{array}{l}\text { Have you ever heard about the Kazakhstan } \\
\text { e-Government portal? }\end{array}$ & 1: Yes, 2: No \\
\hline Q6 & ASOREGOV & $\begin{array}{l}\text { How did you know about Kazakhstan } \\
\text { e-Government portal? }\end{array}$ & $\begin{array}{l}\text { 1: Link from other web-site, } 2 \text { : Internet } \\
\text { search engine, 3: Newspaper, 4: TV, 5: } \\
\text { Radio, 6: Friend/Family member, 0: other }\end{array}$ \\
\hline Q7 & AVISEGOV & $\begin{array}{l}\text { Have you ever visited the Kazakhstan's } \\
\text { e-Government portal? }\end{array}$ & 1: Yes, 2: No \\
\hline Q8 & AFRQEGOV & $\begin{array}{l}\text { How many times do you visit the } \\
\text { e-Government portal per week? }\end{array}$ & $\begin{array}{l}\text { 1: Less than once, } 2: 1-5 \text { times, } 3: 6-9 \text { times } \\
\text { 4: } 10 \text { times and above }\end{array}$ \\
\hline Q9 & $\begin{array}{l}\text { TPUCNTCUR } \\
\text { TPUCNTCOM } \\
\text { TPUCNTACC } \\
\text { TPUCNTNORED } \\
\text { TPUCNTU }\end{array}$ & $\begin{array}{l}\text { Current } \\
\text { Complete } \\
\text { Accurate } \\
\text { Non redundant } \\
\text { Useful }\end{array}$ & $\begin{array}{l}\text { 1: Strongly agree, 2: Moderately } \\
\text { agree, 3: Slightly agree, 4: Neutral, 5: } \\
\text { Slightly disagree, 6: Moderately } \\
\text { disagree, 7: Strongly disagree }\end{array}$ \\
\hline
\end{tabular}


Table A1. Cont.

\begin{tabular}{|c|c|c|c|}
\hline No. & Variable & Description of Variable & Valid Value \\
\hline Q10 & $\begin{array}{l}\text { TPEU } \\
\text { TPEUEUN } \\
\text { TPEUESI } \\
\text { TPEUIF } \\
\text { TPEUHLP } \\
\text { TPEUCONF } \\
\text { TPEUEU } \\
\end{array}$ & $\begin{array}{l}\text { With reference to the Kazakhstan } \\
\text { e-Government portal I find... } \\
\text { it easy to understand } \\
\text { it easy to search for information } \\
\text { it frustrating } \\
\text { I need help while using it } \\
\text { there are too many links that confuse me } \\
\text { it easy to use }\end{array}$ & $\begin{array}{l}\text { 1: Strongly agree, 2: Moderately } \\
\text { agree, 3: Slightly agree, 4: Neutral, 5: } \\
\text { Slightly disagree, 6: Moderately } \\
\text { disagree, 7: Strongly disagree }\end{array}$ \\
\hline Q11 & $\begin{array}{l}\text { TPU } \\
\text { TPUEDUC } \\
\text { TPUHLTH } \\
\text { TPUEMPL } \\
\text { TPUCULT } \\
\text { TPUSPT } \\
\text { TPUTORS }\end{array}$ & $\begin{array}{l}\text { I find the information in following sectors } \\
\text { useful: } \\
\text { Education } \\
\text { Health } \\
\text { Employment } \\
\text { Culture } \\
\text { Sport } \\
\text { Tourism }\end{array}$ & $\begin{array}{l}\text { 1: Strongly agree, 2: Moderately } \\
\text { agree, 3: Slightly agree, } 4 \text { : Neutral, } 5 \text { : } \\
\text { Slightly disagree, } 6 \text { : Moderately } \\
\text { disagree, } 7 \text { : Strongly disagree }\end{array}$ \\
\hline
\end{tabular}

Table A2. Data coding (part 2).

\begin{tabular}{|c|c|c|c|}
\hline No. & Variable & Description of Variable & Valid Value \\
\hline Q12 & $\begin{array}{l}\text { TPU } \\
\text { TPUAIRL } \\
\text { TPUMTRAN } \\
\text { TPUAIRP } \\
\text { TPURAIL } \\
\text { TPUHOT } \\
\text { TPUTRAN } \\
\text { TPUPOS } \\
\text { TPUINT } \\
\text { TPUTEL } \\
\text { TPUEMP } \\
\text { TPUMRS } \\
\text { TPULS }\end{array}$ & $\begin{array}{l}\text { I find the Information on following government and } \\
\text { private services useful: } \\
\text { Airlines } \\
\text { Motor transport } \\
\text { Airports } \\
\text { Railroad stations } \\
\text { Hotels } \\
\text { Transportation } \\
\text { Post } \\
\text { Internet } \\
\text { Telecommunications } \\
\text { Employment } \\
\text { Municipal reference services } \\
\text { Legal services }\end{array}$ & $\begin{array}{l}\text { 1: Strongly agree, } 2 \text { : Moderately } \\
\text { agree, 3: Slightly agree, 4: Neutral, 5: } \\
\text { Slightly disagree, 6: Moderately } \\
\text { disagree, } 7: \text { Strongly disagree }\end{array}$ \\
\hline Q14 & $\begin{array}{l}\text { TPEU } \\
\text { TPEUAIRL } \\
\text { TPEUMTRAN } \\
\text { TPEUAIRP } \\
\text { TPEURAIL } \\
\text { TPEUHOT } \\
\text { TPEUTRAN } \\
\text { TPEUPOS } \\
\text { TPEUINT } \\
\text { TPEUTEL } \\
\text { TPEUEMP } \\
\text { TPEUMRS } \\
\text { TPEULS }\end{array}$ & $\begin{array}{l}\text { I find using following information on government and } \\
\text { private services easy to use: } \\
\text { Airlines } \\
\text { Motor transport } \\
\text { Airports } \\
\text { Railroad stations } \\
\text { Hotels } \\
\text { Transportation } \\
\text { Post } \\
\text { Internet } \\
\text { Telecommunications } \\
\text { Employment } \\
\text { Municipal reference services } \\
\text { Legal services }\end{array}$ & Same as above \\
\hline Q16 & TBIALT & $\begin{array}{l}\text { As I am currently using other sources for the information I } \\
\text { need (e.g.; informal web sites, official resources and mass } \\
\text { media channels) }\end{array}$ & Same as above \\
\hline Q17 & ABARRIER & $\begin{array}{l}\text { What are the reasons for not using/visiting Kazakhstan } \\
\text { e-Government web portal? }\end{array}$ & Same as above \\
\hline
\end{tabular}


Table A3. Data coding (part 3).

\begin{tabular}{|c|c|c|c|}
\hline No. & Variable & Description of Variable & Valid Value \\
\hline Q18 & DGEN & Gender & 1: Male, 2: Female \\
\hline Q19 & DAGE & Age & 1: $16-25,2: 26-35,3: 36-55,4: 56$ and above \\
\hline Q20 & DACCLVL & Academic level & $\begin{array}{l}\text { 1: High school, 2: University Bachelor, 3: University Master, 4: } \\
\text { University PhD }\end{array}$ \\
\hline Q21 & DPLA & Place of staying & 1: Almaty, 2: Astana, 0: other \\
\hline Q22 & DOCCP & Occupation & $\begin{array}{l}\text { 1: Government, 2: Finance, 3: Engineering, 4: IT, 5: Sale, 6: } \\
\text { Student, 7: Unemployed, 0: other }\end{array}$ \\
\hline Q23 & DINCM & Salary range & $\begin{array}{l}\text { 1: under } 15,000 \text { tenge }(\$ 100), 2: 15,001-75,000 \text { tenge }(\$ 100-\$ 500) \text {, } \\
\text { 3: } 75,001-150,000 \text { tenge }(\$ 501-\$ 1000), 4: 150,001-300,000 \text { tenge } \\
(\$ 1001-\$ 2000), 5: \text { Above } 300,000 \text { tenge }(\$ 2000)\end{array}$ \\
\hline
\end{tabular}

\section{Appendix C}

Table A4. Summary of approaches for hypotheses testing.

\begin{tabular}{|c|c|c|c|}
\hline Hypothesis & Variable & Type of Variable & Approach \\
\hline H1 & $\begin{array}{l}\text { PU } \\
\text { PEOU }\end{array}$ & $\begin{array}{l}\text { Numeric } \\
\text { Numeric }\end{array}$ & Linear regression \\
\hline $\mathrm{H} 2$ & $\begin{array}{l}\mathrm{PU} \\
\mathrm{BI}\end{array}$ & $\begin{array}{l}\text { Numeric } \\
\text { Numeric }\end{array}$ & Linear regression \\
\hline H3 & $\begin{array}{l}\mathrm{PU} \\
\mathrm{BI}\end{array}$ & $\begin{array}{l}\text { Numeric } \\
\text { Numeric }\end{array}$ & Linear regression \\
\hline $\mathrm{H} 4$ & $\begin{array}{l}\text { BI } \\
\text { AU }\end{array}$ & $\begin{array}{l}\text { Numeric } \\
\text { Categorical }\end{array}$ & Independent Sample $T$-test \\
\hline H5 & $\begin{array}{l}\text { BI } \\
\text { External factors: Occupation, Academic level }\end{array}$ & $\begin{array}{l}\text { Numeric } \\
\text { Categorical }\end{array}$ & Linear regression \\
\hline
\end{tabular}

Table A5. Component matrix of PU constructs.

\begin{tabular}{ll}
\hline Variables Description & Component \\
\hline With reference to the Kazakhstan e-Government portal I find the content: current & 0.393 \\
\hline With reference to the Kazakhstan e-Government portal I find the content: complete & 0.371 \\
\hline With reference to the Kazakhstan e-Government portal I find the content: accurate & 0.298 \\
\hline With reference to the Kazakhstan e-Government portal I find the content: non redundant & 0.502 \\
\hline With reference to the Kazakhstan e-Government portal I find the content: useful & 0.565 \\
\hline I find the information in following sectors useful: Education & 0.814 \\
\hline I find the information in following sectors useful: Health & 0.822 \\
\hline I find the information in following sectors useful: Employment & 0.779 \\
\hline I find the information in following sectors useful: Culture & 0.828 \\
\hline I find the information in following sectors useful: Sport & 0.702 \\
\hline I find the information in following sectors useful: Tourism & 0.694 \\
\hline I find the Information on following government and private services useful: Airlines & 0.913 \\
\hline I find the Information on following government and private services useful: Motor transport & 0.88 \\
\hline I find the Information on following government and private services useful: Airports & 0.921 \\
I find the Information on following government and private services useful: Railroad stations & 0.906 \\
\hline I find the Information on following government and private services useful: Hotels & 0.897 \\
\hline I find the Information on following government and private services useful: Transportation & 0.835 \\
\hline
\end{tabular}


Table A5. Cont.

\begin{tabular}{ll}
\hline Variables Description & Component \\
\hline I find the Information on following government and private services useful: Post & 0.9 \\
\hline I find the Information on following government and private services useful: Internet & 0.919 \\
\hline I find the Information on following government and private services useful: Telecommunications & 0.934 \\
\hline I find the Information on following government and private services useful: Employment & 0.862 \\
\hline I find the Information on following government and private services useful: Municipal reference services & 0.912 \\
\hline I find the Information on following government and private services useful: Legal services & 0.894 \\
\hline
\end{tabular}

Table A6. Component matrix of PEOU constructs.

\begin{tabular}{|c|c|}
\hline Variables Description & Component \\
\hline With reference to the Kazakhstan e-Government portal I find...it easy to understand & 0.587 \\
\hline With reference to the Kazakhstan e-Government portal I find...it easy to search for information & 0.644 \\
\hline With reference to the Kazakhstan e-Government portal I find...it frustrating & 0.084 \\
\hline With reference to the Kazakhstan e-Government portal I find...I need help while using it & 0 \\
\hline With reference to the Kazakhstan e-Government portal I find...there are too many links that confuse me & -0.06 \\
\hline With reference to the Kazakhstan e-Government portal I find...it easy to use & 0.572 \\
\hline I can find relevant and appopriate information that I need easily in the following sectors: Education & 0.791 \\
\hline I can find relevant and appopriate information that I need easily in the following sectors: Health & 0.75 \\
\hline I can find relevant and appopriate information that I need easily in the following sectors: Employment & 0.737 \\
\hline I can find relevant and appopriate information that I need easily in the following sectors: Culture & 0.789 \\
\hline I can find relevant and appopriate information that I need easily in the following sectors: Sport & 0.766 \\
\hline I can find relevant and appopriate information that I need easily in the following sectors: Tourism & 0.785 \\
\hline I find using following information on government and private services easy to use: Airlines & 0.909 \\
\hline I find using following information on government and private services easy to use: Motor transport & 0.917 \\
\hline I find using following information on government and private services easy to use: Airports & 0.911 \\
\hline I find using following information on government and private services easy to use: Railroad stations & 0.918 \\
\hline I find using following information on government and private services easy to use: Hotels & 0.935 \\
\hline I find using following information on government and private services easy to use: Transportation & 0.9 \\
\hline I find using following information on government and private services easy to use: Post & 0.903 \\
\hline I find using following information on government and private services easy to use: Internet & 0.922 \\
\hline I find using following information on government and private services easy to use: Telecommunications & 0.929 \\
\hline I find using following information on government and private services easy to use: Employment & 0.892 \\
\hline I find using following information on government and private services easy to use: Municipal reference services & 0.896 \\
\hline I find using following information on government and private services easy to use: Legal services & 0.925 \\
\hline
\end{tabular}

Table A7. Component matrix of BI constructs.

\begin{tabular}{lc}
\hline Variables Description & Component \\
\hline $\begin{array}{l}\text { I would like to use e-Government web portal because it helps me: To reduce } \\
\text { my expenses }\end{array}$ & 0.862 \\
\hline $\begin{array}{l}\text { I would like to use e-Government web portal because it helps me: To reduce my } \\
\text { time spent }\end{array}$ & 0.847 \\
\hline $\begin{array}{l}\text { I would like to use e-Government web portal because it helps me: To } \\
\text { minimize bureaucracy }\end{array}$ & 0.904 \\
\hline $\begin{array}{l}\text { I would like to use e-Government web portal because it helps me: To get latest } \\
\text { information and news }\end{array}$ & 0.871 \\
\hline $\begin{array}{l}\text { I would like to use e-Government web portal because it helps me: To get quick } \\
\text { responses for inquiries }\end{array}$ & 0.887 \\
\hline $\begin{array}{l}\text { Although I am currently using other sources for the information I need (e.g., informal } \\
\text { web sites, official resources and mass media channels) I would use the portal }\end{array}$ & 0.166 \\
\hline
\end{tabular}




\section{Appendix D}

Table A8. Results of hypotheses testing (H1, H2, H3, H5).

\begin{tabular}{|c|c|c|c|c|c|}
\hline No. & Model & R-square & B & Sig. & Result \\
\hline $\mathrm{H} 1$ & $\begin{array}{l}\text { PU }=\text { PEOU }+ \text { error } \\
\text { PEOU }\end{array}$ & 0.542 & 0.685 & $p<0.01$ & Accepted \\
\hline $\mathrm{H} 2$ & $\begin{array}{l}\mathrm{BI}=\mathrm{PU}+\text { error } \\
\mathrm{PU}\end{array}$ & 0.199 & 0.475 & $p<0.01$ & Accepted \\
\hline $\mathrm{H} 3$ & $\begin{array}{l}\mathrm{BI}=\mathrm{PEOU}+\text { error } \\
\mathrm{PEOU}\end{array}$ & 0.048 & 0.228 & $p<0.165$ & Rejected \\
\hline $\mathrm{H} 4$ & $\begin{array}{l}\text { BI = PU + PEOU + Occupation }+ \\
\text { Academic level + error } \\
\text { PU } \\
\text { PEOU } \\
\text { Occupation } \\
\text { Academic level }\end{array}$ & 0.477 & $\begin{array}{l}0.477 \\
0 \\
-0.155 \\
0\end{array}$ & $\begin{array}{l}p<0.165 \\
p<0.36 \\
p<0.05 \\
p<0.862\end{array}$ & Rejected \\
\hline
\end{tabular}

Table A9. Result of Hypothesis 4 (Independent Sample T-test).

\begin{tabular}{llllll}
\hline No. & Model & \multicolumn{2}{l}{ Levene's Test for Equality of Variances } & Sig. & Result \\
\hline & & F & Sig. & & \\
\hline H4 & AU = BI + error & 1.32 & 0.25 & $p<0.139$ & Rejected \\
\hline
\end{tabular}

\section{Appendix E}

Table A10. Ranking of information sectors by mean score of PU.

\begin{tabular}{lll}
\hline \multirow{2}{*}{ Sectors } & \multicolumn{2}{c}{ PU } \\
\cline { 2 - 3 } & Mean & Std. Deviation \\
\hline Education & 2.6 & 1.321 \\
Employment & 2.68 & 1.371 \\
Health & 2.73 & 1.394 \\
Culture & 2.98 & 1.374 \\
Sport & 3.15 & 1.377 \\
Tourism & 3.21 & 1.392 \\
\hline
\end{tabular}

Table A11. Ranking for information about services by mean score of PU.

\begin{tabular}{lll}
\hline \multirow{2}{*}{ Services } & \multicolumn{2}{c}{ PU } \\
\cline { 2 - 3 } & Mean & Std. Deviation \\
\hline Airports & 2.98 & 1.537 \\
Municipal reference services & 2.98 & 1.705 \\
Railroad stations & 3.03 & 1.553 \\
Airlines & 3.05 & 1.49 \\
Motor transport & 3.08 & 1.535 \\
Telecommunications & 3.09 & 1.654 \\
Post & 3.1 & 1.528 \\
Internet & 3.1 & 1.626 \\
Legal services & 3.12 & 1.68 \\
Hotels & 3.21 & 1.472 \\
Employment & 3.28 & 1.641 \\
Transportation & 3.33 & 1.538 \\
\hline
\end{tabular}


Table A12. Ranking of information sectors by mean score of PEOU.

\begin{tabular}{lll}
\hline \multirow{2}{*}{ Services } & \multicolumn{2}{c}{ PU } \\
\cline { 2 - 3 } & Mean & Std. Deviation \\
\hline Education & 2.95 & 1.301 \\
Health & 3.16 & 1.554 \\
Employment & 3.24 & 1.401 \\
Culture & 3.36 & 1.257 \\
Sport & 3.39 & 1.317 \\
Tourism & 3.39 & 1.386 \\
\hline
\end{tabular}

Table A13. Ranking for information about services by mean score of PEOU.

\begin{tabular}{lll}
\hline \multirow{2}{*}{ Services } & \multicolumn{2}{c}{ PU } \\
\cline { 2 - 3 } & Mean & Std. Deviation \\
\hline Airlines & 3.4 & 1.334 \\
Motor transport & 3.41 & 1.332 \\
Airports & 3.37 & 1.358 \\
Railroad stations & 3.37 & 1.397 \\
Hotels & 3.52 & 1.348 \\
Transportation & 3.59 & 1.247 \\
Post & 3.45 & 1.361 \\
Internet & 3.43 & 1.386 \\
Telecommunications & 3.44 & 1.376 \\
Employment & 3.6 & 1.314 \\
Municipal reference services & 3.49 & 1.526 \\
Legal services & 3.46 & 1.414 \\
\hline
\end{tabular}

\section{References}

1. Choudrie, J.; Ghinea, G.; Weerakkody, V. Evaluating global e-government sites: A view using web diagnostics tools. Acad. Conf. Int. 2004, 2, 105-114.

2. Carter, L.; Bélanger, F. The utilization of e-government services: Citizen trust, innovation and acceptance factors. Inf. Syst. J. 2005, 15, 5-25. [CrossRef]

3. Tan, M. Plugging into the wired world: Perspectives from Singapore. Inf. Commun. Soc. 1998, 1, $217-245$. [CrossRef]

4. Rahman, H. E-government readiness: From the design table to the grass roots. In Proceedings of the 1st International Conference on Theory and Practice of Electronic Governance, Macao, China, 10-13 December 2007; pp. 225-232.

5. Raguseo, E.; Ferro, E. e-Government and organizational changes: Towards an extended governance model. In International Conference on Electronic Government; Springer: Berlin, Germany, 2011; pp. 418-430.

6. Heeks, R. e-Government as a Carrier of Context. J. Public Policy 2005, 25, 51-74. [CrossRef]

7. Ndou, V. E-Government for developing countries: Opportunities and challenges. Electr. J. Inf. Syst. Dev. Countr. 2004, 18, 1-24. [CrossRef]

8. Ziemba, E.; Papaj, T.; Żelazny, R.; Jadamus-Hacura, M. Factors influencing the success of e-government. J. Comput. Inf. Syst. 2016, 56, 156-167. [CrossRef]

9. Ziemba, E.; Papaj, T.; Jadamus-Hacura, M. Adopting state and local e-government: Empirical evidence from poland. In Proceedings of the 16th European Conference on e-Government, Ljubljana, Slovenia, 16-17 June 2016; Volume 1, pp. 255-264.

10. Song, H.J. e-Government in Developing Countries: Lessons Learned From Republic of Korea; Communication and Information (CI) in Asia, United Nations Educational, Scientific and Cultural Organisation: Paris, France, 2006.

11. Nazarbayev, N. Address of the President of the Republic of Kazakhstan to the People of Kazakhstan. 2004. Available online: http:/ / www.akorda.kz/ (accessed on 20 November 2018). 
12. Yessekeev, K. A Large Amount of Money Was Spent on E-Government Realization. 2008. Available online: https: / profit.kz (accessed on 21 November 2018).

13. Sheryazdanova, G.; Butterfield, J. E-government as an anti-corruption strategy in Kazakhstan. J. Inf. Technol. Polit. 2017, 14, 83-94. [CrossRef]

14. Electronic Government of RK. Electronic Government of the Republic of Kazakhstan. Available online: https: / / egov.kz/ (accessed on 21 November 2018).

15. Des Nations Unies, Organisation. United Nations E-Government Survey 2018; des Nations Unies, Organisation: New York, NY, USA, 2018; p. 298. [CrossRef]

16. United Nations. United Nations E-Government Survey 2016; United Nations: New York, NY, USA, 2017; p. 239. [CrossRef]

17. United Nations. United Nations e-Government Survey 2014; United Nations: New York, NY, USA, $2014 ;$ p. 281. [CrossRef]

18. United Nations. United Nations e-Government Survey 2012; United Nations: New York, NY, USA, 2012; p. 158. [CrossRef]

19. United Nations. United Nations E-Government Survey 2010; United Nations: New York, NY, USA, $2010 ;$ p. 137. [CrossRef]

20. United Nations. United Nations E-Government Survey 2008; United Nations: New York, NY, USA, 2008 ; p. 243. [CrossRef]

21. Electronic Government News. Number of eGov.kz Portal Users Exceeded 8.6 million. Available online: https:/ / egov.kz/cms/en/news/polzovateli_egov (accessed on 1 May 2020).

22. Bhuiyan, S.H. E-government in Kazakhstan: Challenges and its role to development. Public Organ. Rev. 2010, 10, 31-47. [CrossRef]

23. Al-Khateeb, F.B. Predicting internet usage in two emerging economies using an extended technology acceptance model (TAM). In Proceedings of the International Symposium on Collaborative Technologies and Systems, Orlando, FL, USA, 25 May 2007; pp. 143-149.

24. Lin, C.S.; Wu, S. Exploring the impact of online service quality on portal site usage. In Proceedings of the International Conference on the 35th Annual Hawaii, Big Island, HI, USA, 10 January 2002; pp. 2654-2661.

25. Liu, Y.; Chen, Y.; Zhou, C. Exploring success factors for web-based e-government services: Behavioral perspective from end users. In Proceedings of the Information and Communication Technologies, Damascus, Syria, 24-28 April 2006; Volume 1, pp. 937-942.

26. Morris, M.G.; Dillon, A. How user perceptions influence software use. IEEE Softw. 1997, 14, 58-65. [CrossRef]

27. van der Heijden, H. Factors influencing the usage of websites: The case of a generic portal in The Netherlands. Inf. Manag. 2003, 40, 541-549. [CrossRef]

28. Shyu, S.H.P.; Huang, J.H. Elucidating usage of e-government learning: A perspective of the extended technology acceptance model. Gov. Inf. Q. 2011, 28, 491-502. [CrossRef]

29. Zawaideh, F. Acceptance of E-Government Services among Jordanian Citizen. Int. J. Recent Adv. Multidiscip. Res. 2016, 4, 2348-2351.

30. Sang, S.; Lee, J.D.; Lee, J. E-government adoption in ASEAN: The case of Cambodia. Internet Res. 2009, 19, 517-534. [CrossRef]

31. Karavasilis, I.; Vrana, V.G.; Zafiropoulos, K. An extended model of e-government adoption by civil servants in Greece. Int. J. Electr. Gov. Res. (IJEGR) 2016, 12, 1-23. [CrossRef]

32. Colesca, S.E.; Dobrica, L. Adoption and use of e-government services: The case of Romania. J. Appl. Res. Technol. 2008, 6, 204-217. [CrossRef]

33. Alryalat, M.; Dwivedi, Y.K.; Williams, M.D.; Rana, N.P. Examining Role of Usefulness, Ease of Use and Social Influence on Jordanian Citizen's Intention to Adopt E-Government. 2013. p. 4. Available online: https: / / aisel.aisnet.org/ cgi/viewcontent.cgi?article=1003\&context=ukais2013 (accessed on 6 July 2020).

34. AlAwadhi, S.; Morris, A. The Use of the UTAUT Model in the Adoption of E-government Services in Kuwait. In Proceedings of the 41st Annual Hawaii International Conference on System Sciences, Big Island, HI, USA, 7-10 January 2008; p. 219.

35. Davis, F.D.; Bagozzi, R.P.; Warshaw, P.R. User acceptance of computer technology: A comparison of two theoretical models. Manag. Sci. 1989, 35, 982-1003. [CrossRef] 
36. Money, W.; Turner, A. Application of the technology acceptance model to a knowledge management system. In Proceedings of the International Conference on 37th Annual Hawaii, Big Island, HI, USA, 5-8 January 2004; p. 9.

37. Fishbein, M.; Ajzen, I. Belief, Attitude, Intention and Behavior: An Introduction to Theory and Research; Addison-Wesley: Boston, MA, USA, 1975.

38. Ajzen, I.; Fishbein, M. Understanding Attitudes and Predicting Social Behaviour; Pearson: London, UK, 1980.

39. Yousafzai, S.Y.; Foxall, G.R.; Pallister, J.G. Technology acceptance: A meta-analysis of the TAM: Part 1. J. Model. Manag. 2007, 2, 251-280. [CrossRef]

40. Adams, D.A.; Nelson, R.R.; Todd, P.A. Perceived usefulness, ease of use, and usage of information technology: A replication. MIS Q. 1992, 1992, 227-247. [CrossRef]

41. Jackson, C.M.; Chow, S.; Leitch, R.A. Toward an Understanding of the Behavioral Intention to Use an Information System. Dec. Sci. 1997, 28, 357-389. [CrossRef]

42. Taylor, S.; Todd, P.A. Understanding information technology usage: A test of competing models. Inf. Syst. Res. 1995, 6, 144-176. [CrossRef]

43. Ard-Barton, D.L. Implementation characteristics of organizational innovations: Limits and opportunities for management strategies. Commun. Res. 1988, 15, 603-631. [CrossRef]

44. Brown, S.A.; Massey, A.P.; Montoya-Weiss, M.M.; Burkman, J.R. Do I really have to? User acceptance of mandated technology. Eur. J. Inf. Syst. 2002, 11, 283-295. [CrossRef]

45. Venkatesh, V. Creation of favorable user perceptions: Exploring the role of intrinsic motivation. MIS Q. 1999, 1999, 239-260. [CrossRef]

46. Keil, M.; Beranek, P.M.; Konsynski, B.R. Usefulness and ease of use: Field study evidence regarding task considerations. Dec. Support Syst. 1995, 13, 75-91. [CrossRef]

47. Igbaria, M.; Zinatelli, N.; Cragg, P.; Cavaye, A.L. Personal computing acceptance factors in small firms: A structural equation model. MIS Q. 1997, 1997, 279-305. [CrossRef]

48. Hong, W.; Thong, J.Y.; Wong, W.M.; Tam, K.Y. Determinants of user acceptance of digital libraries: An empirical examination of individual differences and system characteristics. J. Manag. Inf. Syst. 2002, 18, 97-124. [CrossRef]

49. Compeau, D.; Higgins, C.A.; Huff, S. Social cognitive theory and individual reactions to computing technology: A longitudinal study. MIS Q. 1999, 1999, 145-158. [CrossRef]

50. Morris, M.G.; Venkatesh, V. Age differences in technology adoption decisions: Implications for a changing work force. Person. Psychol. 2000, 53, 375-403. [CrossRef]

51. Agarwal, R.; Prasad, J. Are individual differences germane to the acceptance of new information technologies? Dec. Sci. 1999, 30, 361-391. [CrossRef]

52. Pitkow, J.E.; Recker, M.M. Using the Web as a survey tool: Results from the second WWW user survey. Comput. Netw. ISDN Syst. 1995, 27, 809-822. [CrossRef]

53. van Selm, M.; Jankowski, N.W. Conducting online surveys. Q. Quant. 2006, 40, 435-456. [CrossRef]

54. Choudrie, J.; Dwivedi, Y. A survey of citizens' awareness and adoption of e-government initiatives, the 'Government Gateway': A United Kingdom perspective. In eGovernment Workshop'05 (eGOV05); Brunel University: London, UK, 2005.

55. Lee, C.B.P.; Lei, U. Adoption of e-government services in Macao. In Proceedings of the 1st International Conference on Theory and Practice of Electronic Governance, Macao, China, 10-13 December 2007; pp. 217-220.

56. Soury, M.; Ziaee, Z.; Shenassa, M.H. The influential factors in employing IRAN E-government portal: Survey of information quality. In Proceedings of the 3rd International Conference on Information and Communication Technologies: From Theory to Applications, Damascus, Syria, 7-11 April 2008; pp. 1-5.

57. Bluman, A.G. Elementary Statistics: A Step by Step Approach; WCB/McGraw-Hill: Boston, MA, USA, 1992.

58. Tabachnick, B.G.; Fidell, L.S. Using Multivariate Statistics; Allyn \& Bacon/Pearson Education: Boston, MA, USA, 2007.

59. Hair, J.F.; Anderson, R.E.; Tatham, R.L.; Black, W.C. Multivariate Data Analysis; Prentice Hall: Upper Saddle River, NJ, USA, 1998.

60. Carver, R.H.; Nash, J.G. Doing Data Analysis with SPSS 10.0; Duxbury Resource Center: Victoria, BC, Canada, 2000.

61. Urdan, T.C. Statistics in Plain English; Routledge: London, UK, 2011. 
62. Anderson, N. The Internet in Kazakhstan: Welcome to the Land of \$3355 Per Month DSL. 2007. Available online: https:/ / arstechnica.com (accessed on 20 November 2018).

63. Litvishko, O.; Beketova, K.; Akimova, B.; Azhmukhamedova, A.; Islyam, G. Impact of the Digital Economy on the Banking Sector. EDP Sci. 2020, 159, 04033. [CrossRef]

64. Kassen, M. Open data in Kazakhstan: Incentives, implementation and challenges. Inf. Technol. People 2017, 30, 301-323. [CrossRef]

(C) 2020 by the authors. Licensee MDPI, Basel, Switzerland. This article is an open access article distributed under the terms and conditions of the Creative Commons Attribution (CC BY) license (http://creativecommons.org/licenses/by/4.0/). 